\title{
Lipid Processing Technology: Building a Multilevel Modeling Network
}

Diaz Tovar, Carlos Axel; Mustaffa, Azizul Azri; Hukkerikar, Amol; Quaglia, Alberto; Sin, Gürkan; Kontogeorgis, Georgios; Sarup, Bent; Gani, Rafiqul

Publication date:

2011

Document Version

Publisher's PDF, also known as Version of record

Link back to DTU Orbit

Citation (APA):

Diaz Tovar, C. A., Mustaffa, A. A., Hukkerikar, A., Quaglia, A., Sin, G., Kontogeorgis, G., Sarup, B., \& Gani, R. (2011). Lipid Processing Technology: Building a Multilevel Modeling Network. Abstract from 21 st European Symposium on Computer Aided Process Engineering, Chalkidiki, Greece.

\section{General rights}

Copyright and moral rights for the publications made accessible in the public portal are retained by the authors and/or other copyright owners and it is a condition of accessing publications that users recognise and abide by the legal requirements associated with these rights.

- Users may download and print one copy of any publication from the public portal for the purpose of private study or research.

- You may not further distribute the material or use it for any profit-making activity or commercial gain

- You may freely distribute the URL identifying the publication in the public portal 


\title{
Lipid Processing Technology: Building a Multilevel Modeling Network
}

\author{
Carlos Axel DIAZ-TOVAR ${ }^{1}$, Azizul Azri MUSTAFFA ${ }^{1}$, Amol HUKKERIKAR ${ }^{1}$, Alberto QUAGLIA ${ }^{1}$, \\ Gürkan SIN $^{1}$, Georgios KONTOGEORGIS ${ }^{2}$, Bent SARUP ${ }^{3}$, Rafiqul GANI*¹. \\ ${ }^{1}$ CAPEC, Department of Chemical and Biochemical Engineering, \\ Technical University of Denmark, DK-2800 Kgs. Lyngby, Denmark. \\ ${ }^{2}$ CERE, Department of Chemical and Biochemical Engineering, \\ Technical University of Denmark, DK-2800 Kgs. Lyngby, Denmark. \\ ${ }^{3}$ Vegetable Oil Technology Business Unit, Alfa Laval Copenhagen A/S, 2860, Denmark \\ * Corresponding author. E-mail: rag@kt.dtu.dk; Tel.: +45-45252882; Fax: +45-45932906.
}

\begin{abstract}
:
Over the past few decades, the world's fats and oils production has been growing rapidly, far beyond the need for human nutrition. This overproduction combined with the growing consumer preferences for healthier food products and the interest in bio-fuels, has led the oleo chemical industry to face in the upcoming years major challenges in terms of design and development of better products and more sustainable processes.

Although the oleo chemical industry is mature and based on well established processes, the complex systems that lipid compounds form, the lack of accurate predictive models for their physical properties and unit operation models for their processing have limited computeraided methods and tools for process synthesis, modeling and simulation to be widely used for design, analysis, and optimization of these processes.

In consequence, the aim of this work is to present the development of a computer aided multilevel modeling network consisting a collection of new and adopted models, methods and tools for the systematic design and analysis of processes employing lipid technology. This is achieved by decomposing the problem into four levels of modeling: 1. pure component properties; 2 . mixtures and phase behavior; 3 . unit operations; and 4. process synthesis and design.

The methods and tools in each level include: For the first level, a lipid-database of collected experimental data from the open literature, confidential data from industry and generated data from validated predictive property models; as well as modeling tools for fast adoptionanalysis of property prediction models.

In the second level, phase behaviors (VLE, LLE and SLE) of relevant lipid mixtures are predicted using the UNIFAC-Cl model where missing group interaction parameters are predicted using the $\mathrm{GC}^{\text {Plus }}$ approach (connectivity index). A master parameter table is prepared for this purpose.

In the third level, a detailed computer aided model analysis of unit operations encountered in oleo chemical industry (eg. Transesterification, Hydrogenation, Interesterification etc.), optimal design, operation and control of these unit operations with respect to performance parameters such as minimum total cost, product yield improvement, operability etc., and process intensification for the retrofit of existing biofuel plants.

In the fourth level the information and models developed are used as building blocks in the development of methods and tools for computer-aided synthesis and design of process flowsheets (CAFD), feasibility assessment and comparison of the alternative flowsheets at their optimal operating points and optimization of the selected alternative with respect to cost and sustainability indicators.
\end{abstract}

Keywords: Lipid Technology, Multilevel Modeling, Property Prediction Models, Process Design, Computer Aided Flow sheet design 